\section{idenotiune}

Jurnal Kajian Manajemen Dakwah

\title{
Sekolah Literasi Indonesia: Filantropi Islam dan Pelayanan Pendidikan Bagi Masyarakat Pedalaman
}

\author{
Muhammad Irham ${ }^{1}$ \\ ${ }^{1}$ Universitas Abdurrab Pekanbaru \\ Email: muhammad.irham@univrab.ac.id
}

\begin{abstract}
This study aimed to reveal the practice of Islamic philanthropy in the community empowerment program initiated by Dompet Dhuafa Riau in the Talang Mamak Community as one of the inland communities in Riau Province. Specifically, this study traced the Indonesian Literacy School (SLI) program which was engaged in education. This research was a field research with a qualitative approach. The data in this study were obtained through observation, documentation and interviews. This research showed that the implementation of the Indonesian Literacy School program was motivated by the backward condition of the Talang Mamak Community in the field of education. The program was run by volunteer teachers who were sent on a sedentary basis to accompany, foster and empower them. Finally, this research concluded that the practice of Islamic philanthropy in the SLI program was not only in the form of direct services but also in the form of long-term empowerment. This research also showed that the SLI program was implemented with an Islamic philanthropic scheme by utilizing philanthropic funds such as zakat, infaq, alms and charity.
\end{abstract}

Keywords: Islamic Philanthropy, SLI, Talang Mamak

\begin{abstract}
Abstrak: Penelitian ini bertujuan untuk mengungkap praktik filantropi Islam pada program pemberdayaan masyarakat yang diinisiasi oleh Dompet Dhuafa Riau pada Komunitas Talang Mamak sebagai salah satu masyarakat pedalaman di Provinsi Riau. Secara spesifik, penelitian ini menelusuri program Sekolah Literasi Indonesia(SLI) yang bergerak di bidang pendidikan. Penelitian ini merupakan penelitian lapangan dengan pendekatan kualitatif. Data dalam penelitian ini diperoleh melalui observasi, dokumentasi dan wawancara. Penelitian ini menunjukkan bahwa pelaksanaan program Sekolah Literasi Indonesia dilatarbelakangi oleh kondisi keterbelakangan Komunitas Talang Mamak dalam bidang pendidikan. Program tersebut dijalankan oleh guru relawan yang dikirimkan dengan pola menetap untuk mendampingi, membina dan memberdayakan mereka. Akhirnya, penenlitian ini berkesimpulan bahwa praktik filantropi Islam pada program SLI ini tidak hanya dalam bentuk pelayanan langsung tetapi juga dalam bentuk pemberdayaan jangka panjang. Penelitian ini juga menunjukkan bahwa program SLI ini dilaksanakan dengan skema filantropi Islam dengan memanfaatkan dana filantropi seperti zakat, infaq, sedekah dan wakaf.
\end{abstract}

Kata kunci: Filantropi Islam, SLI, Talang Mamak

\section{Pendahuluan}

Hadirnya berbagai program yang diinisiasi oleh lembaga filantropi Islam di Indonesia, menunjukkan adanya perkembangan praktik filantropi. Program yang dilakukan tidak hanya berorientasi dalam bentuk pemberian langsung yang bersifat konsumtif, karikatif dan jangka pendek. Tetapi juga mengarah bahkan lebih menekankan pada aktivitas pemberdayaan masyarakat secara berkelanjutan dan jangka panjang. Hal ini ditandai dengan munculnya sejumlah Lembaga Amil Zakat pasca Reformasi yang menawarkan program dan kegiatan 
yang lebih bervariasi dalam rangka memberdayakan masyarakat terutama bagi masyarakat yang kurang beruntung (Latief, 2013: 9).

Lebih luas, program yang dilakukan oleh sejumlah Lembaga Amil Zakat di Indonesia tersebut, tidak hanya berorientasi pada satu bidang tertentu, tetapi mengarah pada program pemberdayaan masyarakat dalam berbagai bidang yang disesuaikan dengan kebutuhan masyarakat yang menjadi sasaran pemberdayaan. Sehingga programnya bervariasi baik di bidang dakwah, pendidikan, ekonomi, kesehatan, politik maupun sosial dalam rangka mewujudkan kemandirian dan perubahan sosial bagi masyarakat yang menjadi penerima manfaat program dengan menekankan pada prinsip keadilan dan kesetaraan (Latief, 2017: 19).

Artikel ini berupaya menyoroti praktik filantropi pada program pemberdayaan masyarakat yang diinisiasi oleh Lembaga Amil Zakat. Studi-studi yang telah ada menunjukkan bahwa hadirnya sejumlah Lembaga Amil Zakat menguatkan praktik filantropi Islam di Indonesia. Praktik filantropi yang dilaksanakan tidak hanya berorientasi pada praktik filantropi tradisional yang mengarah pada kegiatan pelayanan dan pemberian langsung, tetapi juga mengarah pada praktik filantropi modern yang mengarah pada penguatan pemberdayaan masyarakat yang bersifat jangka panjang. Diantara sarjanawan yang meneliti praktik filantropi dalam penguatan pemberdayaan masyarakat melalui peran lembaga filantropi berbasis komunitas adalah Hilman Latief (2010: 503-553; 2017), Ariza Fuaddi (2012: 92-102), dan Minako Sakai (2014: 201-222).

Secara spesifik, artikel ini berupaya menelusuri praktik filantropi Islam pada program Sekolah Literasi Indonesia yang diinisiasi oleh Lembaga Amil Zakat Dompet Dhuafa Riau. Sebuah program yang bergerak dalam bidang pendidikan dengan pola pendampingan, pembinaan dan pemberdayaan dalam rangka memberikan pelayanan pendidikan dan memberdayakan Komunitas Talang Mamak yang tergolong masyarakat pedalaman di Provinsi Riau. Program Sekolah Literasi Indonesia dilaksanakan sejak tahun 2016 di Komunitas Talang Mamak Desa Rantau Langsat, Kecamatan Batang Gansal, Kabupaten Indragiri Hulu dengan pusat pelaksanaan program di Sekolah Jarak Jauh Dusun Nunusan (Ali Bastoni, Wawancara, Rabu, 05 Februari 2019).

Peneliti melihat bahwa pelaksanaan program Sekolah Literasi Indonesia bagi Komunitas Talang Mamak dilatarbelakangi oleh keterbelakangan komunitas ini dalam bidang pendidikan. Sehingga masyarakat Talang Mamak sangat membutuhkan adanya suatu program pelayanan dan pemberdayaan di bidang pendidikan. Sebagaimana hasil observasi dan wawancara langsung peneliti dengan beberapa orang Komunitas Talang Mamak yang menjadi informan dalam penelitian ini. Warni Berta selaku penggerak Sekolah Jarak Jauh di Dusun Nunusan mengutarakan:

"Dusun Nunusan termasuk dusun paling dalam dan jauh dari pusat desa. Di sana, terdapat sekolah jarak jauh dengan fasilitas terbatas. Aktivitas pendidikannya sering terhambat, bahkan terhenti. Ya.... gurunya tidak ada yang menetap di sana, tentu pendidikannya tidak berjalan lancar, hanya mengharapkan kami di sekolah inti di pusat desa ini saja untuk ke sana, hmmm...tentuk tidak bisa. Menuju lokasi berjam-jam, dan tidak bisal lewat jalan darat, biayanya mahal. Itulah sebabnya banyak anak-anak di sana tidak pandai baca dan tulis. Jadi, mereka memang butuh diberdayakan, datangkan guru 
untuk menetap di sana, mendampingi dan menjalankan kegiatan pendidikan di sana. Pandai mereka membaca, menulis dan berhitung, cukup bagi kami" (Warni Berta, Wawancara, Selasa, 29 Januari 2019).

Berdasarkan permasalahan di atas, pelaksanaan program Sekolah Literasi Indonesia pada Komunitas Talang Mamak khususnya di Dusun Nunusan adalah sebagai respon dan solusi terhadap isu sosial yaitu keterbelakangan atau ketertinggalan melalui skema filantropi Islam. Artikel ini berupaya melihat bagaimana peran Dompet Dhuafa Riau dalam memberdayakan Komunitas Talang Mamak. Lebih lanjut, artikel ini menelusuri bagaimana praktik filantropi yang dilaksanakan pada program Sekolah Literasi Indonesia sebagai program pelayanan dan pemberdayaan pendidikan komunitas tersebut. Sehingga studi ini merupakan kelanjutan dari penelitian sebelumnya yang melihat tentang bagaimana peran lembaga filantropi khususnya Lembaga Amil Zakat dalam upaya penguatan pemberdayaan masyarakat. Namun, berbeda dengan studi-studi sebelumnya, penelitian ini lebih melihat bagaimana peranan Dompet Dhuafa Riau dalam pemberdayaan masyarakat pedalaman melalui aktivitas filantropi dengan fokus kajian pada program Sekolah Literasi Indonesia yang dilaksanakan pada Komunitas Talang Mamak di Desa Rantau Langsat.

Artikel ini berargumen bahwa Lembaga Amil Zakat Dompet Dhuafa Riau berperan dalam mendistribusikan kesejahteraan kepada Komunitas Talang Mamak dalam upaya memberdayakan meraka secara berkelanjutan dengan menyentuh aspek-aspek kebutuhan masyarakat komunitas tersebut yang belum tersentuh oleh perhatian pemerintah melalui pemanfaatan dana-dana filantropi sebagai modal gerakan mereka.

\section{Metode}

Jenis penelitian ini adalah penelitian lapangan dengan menggunakan pendekatan kualitatif. Fokus kajian dalam penelitian ini adalah program Sekolah Literasi Indonesia Dompet Dhuafa Riau pada Komunitas Talang Mamak yang dilihat sebagai praktik filantropi Islam yang mengarah pada aktivitas pemberdayaan. Data dalam penelitian ini diperoleh secara langsung di lapangan, berbaur dengan objek penelitian, wawancara dan mendiskripsikan makna data atau fenomena dengan menunjukkan bukti-bukti (Muhammad Ali, 2011: 241). Informan dalam penelitian ini adalah sejumlah pengurus Dompet Dhuafa Riau dan pelaksana program Sekolah Literasi Indonesia serta sejumlah tokoh dan masyarakat Komunitas Talang Mamak sebagai sasaran program. Data yang diperoleh dianalisis dengan menggunakan analisis kualitatif deskriptif (Ali, 2011: 242), yakni dengan cara memaparkan informasi-informasi aktual yang diperoleh terutama terkait praktik filantropi Islam pada program Sekolah Literasi Indonesia pada Komunitas Talang Mamak.

\section{Hasil dan Pembahasan}

\section{Sekolah Literasi Indonesia: Program Pelayanan Pendidikan dengan Skema Filantropi Islam}

Sekolah Literasi Indonesia atau yang disingkat dengan SLI merupakan sebuah program yang bergerak dibidang pendidikan dengan skema filantropi Islam. program ini diinisiasi oleh Lembaga Amil Zakat Dompet Dhuafa dalam rangka memberikan pelayanan pendidikan 
kepada masyarakat Indonesia khususnya bagi masyarakat marginal, pedalaman dan pendidikannya masih rendah. Secara spesifik, SLI adalah sebuah model sekolah berbasis masyarakat yang berkonsentrasi pada upaya pemberian layanan pendidikan dan peningkatan kualitas sistem instruksional (pembelajaran) dan pengembangan kultur sekolah dengan kekhasan literasi (Dokumen DD Riau: SLI, 2017).

Sekolah Literasi Indonesia merupakan program dari Dompet Dhuafa Pusat yang termasuk ke dalam divisi makmal pendidikan dompet dhuafa. Tujuan utama dari program ini adalah memberikan layanan pendidikan dan meningkatkan mutu pendidikan masyarakat Indonesia yang menjadi sasaran dalam pelaksanaan program. Terdapat tiga sasaran utama dilaksanakannya program SLI ini, diantaranya: Pertama, Sekolah Urban, yang diperuntukkan untuk masyarakat desa yang pindah ke kota dan pendidikannya masih kurang. Kedua, Sekolah Beranda, diperuntukkan bagi masyarakat yang tinggal di daerah marginal, pelosok dan pedalaman, dengan kategori kurangnya guru dan mutu pendidikannya masih rendah. Ketiga, sekolah desa dan kota, yang pendidikannya juga masih kurang (Oky Dwi Ramadiansyah, Wawancara, 31 Januari 2019).

Secara umum, tujuan dilaksakannya program Sekolah Literasi Indonesia ini adalah menyelenggarakan dan mendorong aktivitas pendidikan pada sekolah-sekolah yang belum tersentuh atau dijangkau oleh pemerintah. Sebagaimana di Indonesia, banyaknya jumlah sekolah menyebabkan pemerintah tidak sepenuhnya dapat mencukupi dan menjangkau kebutuhan pendidikan, khususnya bagi masyarakat di daerah-daerah pelosok atau pedalaman di Indonesia. Maka program Sekolah Literasi Indonesia ini adalah suatu upaya memberikan layanan pendidikan dalam rangka mengisi kekosongan negara untuk mendistribusikan kesetaraan terutama bidang pendidikan bagi masyarakat, sehingga pendidikan dapat dinikmati oleh seluruh masyarakat Indonesia tanpa terkecuali (Undang-Undang Dasar 1945 Pasal 31 ayat 1$)$.

Program Sekolah Literasi Indonesia menjadikan sekolah beranda sebagai sasaran utama. Yaitu memberikan layanan pendidikan untuk masyarakat yang tinggal di daerah pelosok atau pedalaman di Indonesia. Program SLI ini dalam perencanaan, dilaksanakan selama tiga tahun dengan kegiatan utama adalah pendampingan, pengkaderan pembinaan dan pemberdayaan dalam rangka memberikan pelayanan dan fasilitas pendidikan yang dapat meningkatkan mutu pendidikan masyarakat terutama di daerah pedalaman atau pulau-pulau kecil di Indonesia. Program ini dilaksanakan dengan cara mengirimkan guru literasi sebagai konsultan relawan untuk menetap di daerah yang telah ditentukan dan bertugas untuk menjalankan program pendampingan dan pembinaaan serta membantu guru lokal dalam menjalankan aktivitas pendidikan, dengan target utama adalah terwujudnya masyarakat pedalaman yang pandai tulis baca (Ali Bastoni, Wawancara, 05 Februari 2019).

Program Sekolah Literasi Indonesia dilaksanakan melalui skema filantropi Islam. Filantropi itu sendiri merujuk pada segala bentuk pemberian dan pelayanan sukarela yang ditujukan untuk kesejahteraan sosial atau kebajikan publik. Setidaknya, terdapat empat unsur yang melekat pada aktivitas filantropi, yaitu sukarela, privat, pemberian atau pelayanan dan kebajikan publik (Martin, 1994: 8). Dalam khazanah Islam, aktivitas filantropi identik dengan praktik zakat, infaq, sedekah dan wakaf. Fauziah mencatat bahwa praktik zakat, infaq, 
sedekah dan wakaf merupakan bagian penting dari kegiatan sukarela yang mulai dilembagakan dalam organisasi sukarela dan nirlaba sejak akhir abad kesembilan belas, sehingga aktivitasnya lebih luas, tidak hanya sekedar pemberian tapi juga mengarah pada pendayagunaan yang lebih terorganisir (Fauziah, 2016: 22).

Sekolah Literasi Indonesia sebagai program pemberdayaan yang diinisiasi oleh Lembaga Amil Zakat Dompet Dhuafa, baik pusat maupun cabang Dompet Dhuafa di seluruh Indonesia dilaksanakan dengan memanfaatkan dana filantropi Islam, seperti zakat, infaq, sedekah, wakaf dan sumbangan dari donatur baik personal maupun komunal yang berhasil dihimpun. Sebagaimana Firman Nuryanto mengutarakan:

"Ya, Dompet Dhuafa, sebagai lembaga filantropi, tentu sumber pendanaannya berasal dari dana filantropi Islam itu sendiri. Baik zakat, infaq, sedekah, wakaf maupun sumbangan sukarela dari masyarakat. Sehingga setiap program yang dilaksanakan terutama yang mengarah pada aktivitas pemberdayaan, sumber dana utamanya berasal dari dana filantropi. Begitu juga dengan program Sekolah Literasi Indonesia. Program ini juga didanai oleh dana filantropi yang berhasil dihimpun. Misalnya Dompet Dhuafa Riau, melaksanakan program ini untuk memberikan pelayanan pendidikan kepada masyarakat pedalaman yang ada di Riau, kami bekerjasama dengan Dompet Dhuafa Pusat, dengan memanfaatkan dana zakat, infaq, sedekah, wakaf dan sumbangan sukarela dalam pelaksanaannya. Hal ini bertujuan agar manfaat dana filantropi itudapat dirasakan oleh semua kalangan, termasuk masyarakat pedalaman yang kurang diperhatikan" (Firman, Wawancara, 22 Januari 2020).

Peneliti melihat bahwa program Sekolah Literasi Indonesia yang diinisiasi oleh Dompet Dhuafa, dengan memanfaatkan dana fialntropi dalam pelaksanaan kegiatannya, selain sebagai upaya memberikan pelayanan pendidikan bagi masyarakat yang membutuhkan, juga sebagai upaya pendistribusian dana filantropi agar masyarakat dapat merasakan manfaat dari dana sosial tersebut, termasuk masyarakat yang tinggal di daerah pelosok atau pedalaman yang sering dilupakan. Sehingga program ini dapat dilihat sebagai upaya Lembaga Amil Zakatsebagai aktor non negara dalam mendistribsuikan kejahteraan bagi masyarakat yang kurang beruntung.

\section{Sekolah Literasi Indonesia: Program Pelayanan Pendidikan dan Pemberdayaan bagi Komunitas Talang Mamak}

Pelaksanaan program Sekolah Literasi Indonesia (SLI) untuk Komunitas Talang Mamak diinisiasi oleh Dompet Dhuafa Riau bekerjasama dengan Dompet Dhuafa Pusat. Program ini terpusat di Dusun Nunusan, Desa Rantau Langsat, Kecamatan Batang Gansal, Kabupaten Indragiri Hulu, Provinsi Riau. Dilaksanakannya program SLI pada Komunitas Talang Mamak ini dilatarbelakangi olehkebutuhan masyarakat akan perlu adanya guru untuk sekolah jarak jauh yang ada di Dusun Nunusan. Di mana, Dusun ini merupakan salah satu dusun yang paling dalam di Desa Rantau Langsat. Untuk sampai ke dusun tersebut menempuh waktu 3 sampai 5 jam perjalanan dari pusat desa, dan tidak bisa ditempuh lewat jalan darat.

Pendidikan untuk anak-anak di Dusun Nunusan berpusat di Sekolah Jarak Jauhyang didirikan oleh pemerintah desa bekerjasama dengan pihak Sekolah SDN 004 Rantau Langsat 
sebagai sekolah inti bagi Komunitas Talang Mamak.Namun, berjalannya waktu, kegiatan pendidikan di sekolah jarak jauh ini mengalami hambatan, disebabkan kurangnya guru dan sulitnya guru untuk mengajar di dusun tersebut, karena akses jalannya yang jauh dan berbahaya sebab masih dikelilingi hutan yang lebat dan membutuhkan biaya yang mahal untuk sampai ke dusun tersebut. Hal ini lah yang mendorong Kepala Sekolah SDN 004 Rantau Langsat yang merangkap sebagai Kepala Sekolah Jarak Jauh ini meminta Dompet Dhuafa untuk mengirimkan guru dan menetap di sana.

"Kami merasa kesulitan dan kewelahan untuk mengajar di sekolah jarak jauh yang ada di Dusun Nunusan. Guru di sekolah inti ini, tidak mampu untuk terus menerus mengajar ke sana. Guru lokal yang ada di sekolah jarak jauh tersebut hanya 1 orang, dan itupun tidak menetap, yang membuatnya kesulitan dalam mengajar. Biaya untuk sampai ke sekolah tersebut dapat mencapai jumlah yang besar sekitar Rp.800.000 untuk sekali jalan atau pulang perginya. Kami tidak mempunyai biaya untuk terus menerus ke sana. Oleh karena itu, kami meminta Dompet Dhuafa Riau, untuk mengirimkan guru yang kompeten dan menetap di sana untuk mengajar di sekolah jarak jauh tersebut, tujuannya agar anak-anak di sana pandai tulis baca dan berhitung, itu lah tujuan utamanya dan harapan saya" (Warni Berta, Wawancara, Selasa, 29 Januari 2019).

Berdasarkan permintaan akan kebutuhan tenaga pengajar untuk Sekolah Jarak Jauh di Dusun Nunusan sebagaimana dijabarkan di atas, mendorong Dompet Dhuafa Riau untuk melaksanakan program Sekolah Literasi Indonesia melalui kerjasama Dompet Dhuafa Pusat dengan mengirimkan guru literasi sebagai konsultan relawan untuk menetap dan mengajar di sana. Hal ini bertujuan untuk membantu terselenggaranya pendidikan bagi anak-anak Talang Mamak khususnya di dusun yang jauh dari pusat desa, sehingga program yang dilaksanakan oleh Dompet Dhuafa Riau tidak hanya menyentuh masyarakat yang ada di sekitar pusat desa, namun juga menjangkau masyarakat Talang Mamak yang hidup di kawasan yang jauh di pelosok dan pedalaman dengan memperhatikan aspek kebutuhan masyarakatnya (Firman Nuryanto, Wawancara, Selasa, 22 Januari 2019).

Di antara faktor yang melatarbelakangi aktivitas pemberdayaan sebagai upaya membimbing masyarakat yang dilakukan oleh suatu organisasi sosial adalah kondisi ketidakpuasan suatu kelompok masyarakat terhadap kondisi di dalam masyarakatnya, yang disebabkan oleh sulitnya mereka dalam memenuhi kebutuhannya. Sehingga pemberdayaan sosial dimaksudkan sebagai upaya memberdayakan mereka dan membantu mereka dalam pemenuhan kebutuhan dan melakukan pengembangan melalui proses bimbingan masyarakat (Soetarso, 1994: 131-132).

Penulis melihat bahwa pelaksanan program Sekolah Literasi Indonesia di Dusun Nunusan yang diinisiasi oleh Dompet Dhuafa Riau juga dilatarbelakangi oleh rasa ketidakpuasan masyarakat terhadap kondisi pendidikan anak-anak Talang Mamak yang kurang diperhatikan. Salah satunya adalah keterbatasan tenaga pengajar bahkan tidak ada, sehingga mereka sangat membutuhkan guru sebagai pendamping dan melakukan pemberdayaan melalui upaya bimbingan masyarakat khususnya anak-anak di Sekolah Jarak Jauh Dusun Nunusan, untuk kebutuhan pendidikan mereka. 
Program Sekolah Literasi Indonesia di Dusun Nunusan mulai dilaksanakan pada tahun 2016, dengan mengirimkan satu orang guru sebagai konsultan relawan dan menjalankan berbagai kegiatan untuk mutu pendidikan anak-anak Talang Mamak di Sekolah Jarak Jauh di Dusun Nunusan. Tujuan utama dari program ini adalah merevitalisasi atau menghidupkan kembali aktivitas pendidikan yang seringkali terhambat dalam pelaksanaannya dan juga sebagai asupan baru bagi mutu pendidikan masyarakat pedalaman dengan metode-metode baru yang nantinya diharapkan dapat membawa perubahan bagi mereka, terutama terwujudnya kemampuan anak-anak Talang Mamak untuk membaca, menulis dan berhitung (Dede, Wawancara, Kamis, 31 Januari 2019).

Hakikatnya, program Sekolah Literasi Indonesia yang diarahkan untuk Komunitas Talang Mamak khususnya di Dusun Nunusan Desa Rantau Langsat bertujuan untuk memberikan pelayanan sebagai bentuk kepedulian terhadap pendidikan masyarakat pedalaman. Masyarakat yang sudah lama merindukan adanya promotor penggerak untuk pendidikan anak-anak mereka. Guru sebagai sumber daya manusianya kurang bahkan tidak ada, sehingga sekolah yang sudah ada meskipun sederhana dan terbatas, belum mampu dimanfaatkan untuk aktivitas pendidikan. Kondisi inilah yang memotivasi perlu adanya program SLI untuk mereka, sehingga mereka dapat merasakan pendidikan seperti masyarakat pada umumnya.

"Kondisi wilayah di Dusun Nunusan, lokasi saya ditempatkan, merupakan suatu wilayah yang masih dikelilingi hutan dan jauh dari pusat desa dan perkotaan, mutu pendidikannya sangat rendah, gurunya tidak ada, aktivitas pendidikan terhambat. Mengapa saya ditempatkan di situ, karena semua masyarakat Indonesia berhak mendapatkan pendidikan. Dengan adanya program ini, kami mencoba untuk memperdulikan, memperhatikan, melayani dan memfasilitasi dalam rangka memberikan hak mereka untuk mendapatkan pendidikan, meskipun tinggal di daerah pedalaman" (Oky, Wawancara, Kamis, 31 Januari 2019).

Latief mencatat bahwa keterlibatan lembaga filantropi dalam kegiatan sosial terutama kegiatan yang mengarah pada upaya pemberdayaan masyarakat jangka panjang adalah suatu upaya untuk memperkenalkan inovasi praktik filantropi Islam yang didorong oleh motif keagamaan dan kepedulian sosial. Kegiatan tersebut adalah upaya mendefinisikan ulang dan mengkonseptualisasikan konsep-konsep Islam terkait zakat, infaq, sedekah, wakaf, tolong menolong (ta'awun) dan kemaslahatan (Latief, 2013: 107-108).

Berdasarkan hal tersebut, peneliti melihat bahwa pelaksanaan program Sekolah Literasi Indonesia adalah sebagai bentuk keterlibatan lembaga filantropi dalam hal ini adalah Dompet Dhuafa Riau dalam program pemberdayaan jangka panjang di bidang pendidikan yang didorong oleh motif keagamaan melalui pemanfaatan dana filantropi seperti zakat, infaq, sedekah dan wakaf dalam pelaksanaannya dan didorong oleh bentuk kepedulian sosial karena kondisi keterbelakangan pendidikan yang menyelimuti Komunitas Talang Mamak khususnya di Dusun Nunusan.

Selain sebagai bentuk kepedulian, pelaksanaan program Sekolah Literasi Indonesia juga sebagai bentuk upaya pengabdian dan tanggung jawab sosial dari lembaga Filantropi Islam. sebagaimana disebutkan di atas, bahwa Sekolah Jarak Jauh yang ada di Dusun 
Nunusan, hanya memiliki satu orang guru dan sering terkendala biaya, karena aksesnya yang sangat jauh. Hal ini lah yang memotivasi Dompet Dhuafa Riau untuk melaksanakan program Sekolah Literasi Indonesia melalui kerjasama dengan Dompet Dhuafa Pusat untuk mengirimkan satu orang guru untuk membantu guru lokal dan sebagai bentuk pengabdian dalam memajukan pendidikan anak-anak Talang Mamak di Dusun Nunusan.

"Motif kami untuk mengirimkan guru di sana, tidak lain dan tidak bukan adalah sebagai tanggung jawab sosial dan pengabdian. Mengabdikan diri bertahun-tahun untuk tinggal menetap di daerah pelosok dan pedalaman. Satu tujuan kami adalah bagaimana masyarakat disana juga dapat menikmati pendidikan. Mengabdikan diri bersama guru lokal dalam rangka membawa perubahan positif bagi pendidikan mereka" (Firman, Wawancara, Selasa, 22 Januari 2019).

Latief dan Mutaqin mencatat bahwa pemberian akses terhadap pendidikan termasuk program unggulan dari Dompet Dhuafa. Lembaga Amil Zakat ini telah memberikan akses dan kesempatan yang lebih besar dalam rangka memperbaiki kehidupan masyarakat dengan cara memperluas pengetahuan, keterampilan dan kreatifitasnya melalui pendidikan. Upaya yang dilakukan mulai dari penyediaan berbagai jenis beasiswa, pemberdayaan guru maupun peningkatan mutu pendidikan di daerah beranda atau daerah tertinggal di berbagai wilayah di Indonesia, dengan mengirimkan guru pendamping untuk melakukan pengabdian dan pemberdayaan guru lokal serta masyarakat yang diberdayakan ke arah yang lebih baik (Latief \& Mutaqin,2015: 325). Dengan demikian dapat dipahami bahwa program Sekolah Literasi Indonesia yang dilaksanakan oleh Dompet Dhuafa Riau pada Komunitas Talang Mamak di Dusun Nunusan tersebut menunjukkan komitmen DD dalam memperhatikan pendidikan masyarakat Indonesia terutama bagi masyarakat yang sulit mendapatkan akses pendidikan seperti halnya masyakat Talang Mamak dengan motif pengabdian dan pemberdayaan.

Lebih luas, pelaksanaan program Sekolah Literasi Indonesia di Dusun Nunusan adalah sebagai bentuk upaya pemberdayaan. Dan ini merupakan tujuan utama. Tujuan ini berangkat dari beberapa kondisi yang menjadi alasan perlunya pemberdayaan di bidang pendidikan untuk Komunitas Talang Mamak tersebut. Diantaranya, tidak adanya guru yang menetap di sana, yang menyebabkan aktivitas pendidikannya tidak berjalan dengan baik. Di mana sekolah jarak jauh di Dusun Nunusan pernah libur selama 6 bulan, dan tidak sama sekali ada kegiatan belajar dan mengajar. Di samping itu, anak-anak Talang Mamak yang duduk di bangku Sekolah Dasar di sekolah jarak jauh ini belum bisa baca, tulis dan berhitung. Begitu juga dengan minat dan perhatian dari orang tua untuk pendidikan anak-anaknya masih kurang.

"Ya, karena gurunya tidak ada, dukungan tidak ada, sekolah sering libur, bahkan libur lebih lama dari sekolahnya, akses ke sekolah nya sangat sulit, tentu orang tuanya, lebih memilih anak-anaknya untuk bekerja dan tidak sekolah. Baru usia kanak-kanak sudah di bawa ke hutan, untuk bekerja dan sebagainya, ini tentu karena perhatian dan dukungan yang tidak berpihak kepada kami khususnya yang tinggal di Dusun Nunusan" (Safarudin, Wawancara, Rabu, 30 Januari 2019).

Melihat kondisi yang memprihatinkan tersebut, maka Dompet Dhuafa Riau menilai dan memutuskan bahwa Komunitas Talang Mamak di Dusun Nunusan perlu di bantu, perlu 
dukungan, perlu diberdayakan terutama pendidikan mereka. Maka program Sekolah Literasi Indonesia dibawah naungan Dompet Dhuafa Pusat adalah solusi yang tepat untuk pemberdayaan mereka. Maka program SLI ini dilaksanakan oleh Dompet Dhuafa Riau di Dusun Nunusan dengan meminta kerjasama Dompet Dhuafa Pusat untuk mengirimkan guru langsung dari pusat melalui divisi makmal pendidikan Dompet Dhuafa (Dede, Wawancara, Kamis, 31 Januari 2019).

Peneliti melihat bahwa tujuan dari pelaksanaan program Sekolah Literasi Indonesia yang diinisiasi oleh Dompet Dhuafa sebagai fasilitatorprogram pemberdayaan sebagaimana disebutkan di atas, sejalan dengan pola pendukungan dan bantuan dalam konteks pemberdayaan masyarakat yang dikenal dengan istilah pendampingan. Yefni menjelaskan bahwa pendampingan dalam konteks pemberdayaan masyarakat merujuk pada upaya memberikan kemudahan dan berupaya memberikan solusi terhadap permasalahan yang dihadapi oleh masyarakat yang diberdayakan melalui pengadaan personil, tenaga pendamping, relawan atau pihak lain yang berperan memberikan penerangan bimbingan, terapi psikologis dan penyadaran agar masyarakat yang sebelumnya tidak tahu menjadi tahu dan tumbuhnya kesadaran untuk berubah (Yefni, 2014: 121).

Lebih dari itu, penjabaran di atas, juga menunjukkan bahwa program Sekolah Literasi Indonesia yang dilaksanakan di Dusun Nunusan untuk Komunitas Talang Mamak adalah program kreatif untuk pemberdayaan masyarakat di bidang pendidikan dan sebagai bukti Dompet Dhuafa Riau sebagai Lembaga Amil Zakat telah mengambil peran penting dalam mengabdi untuk kepentingan dan kebutuhan masyarakat dalam upaya mengisi kekosongan negara bagi pendidikan masyarakat yang kurang beruntung dan kurang diperhatikan.

\section{Sekolah Literasi Indonesia dan Praktik Filantropi Islam}

Program Sekolah Literasi Indonesia yang diinisiasi oleh Dompet Dhuafa Riau sebagai upaya pemberian layanan pendidikan dan pemberdayaan Komunitas Talang Mamak di Desa Rantau Langsat dapat dibaca sebagai aktivitas filantropi Islam. Hal ini ditandai oleh inisiator dari pelaksanaan program, yaitu Lembaga Amil Zakat melalui pemanfaatan dana filantropi Islam seperti zakat, infaq, sedekah dan wakaf dalam pelaksanaan program tersebut. Di samping itu, program Sekolah Literasi Indonesia dikatakan sebagai praktik filantropi, juga ditandai dengan upaya pendistribusian kesetaraan kepada masyarakat yang kurang beruntung melalui kegiatan memberi, belas kasih, pendampingan, pembinaan dan pemberdayaan terutama dalam memenuhi kebutuhan Komunitas Talang Mamak di Desa Rantau Langsat khususnya di bidang pendidikan.

Praktik filantropi Islam yang dilaksanakan pada program Sekolah Literasi Indonesia untuk Komunitas Talang Mamak dapat dikategorikan kedalam dua bentuk praktik filantropi pada umumnya, yakni filantropi tradisional (Studi Fuadi, 2012: 96) dan filantropi modern (studi Fuadi, 2012: 96; Latief, 2017: 33). Filantropi tradisional direalisasaikan dalam bentuk karitas atau pelayanan langsung yang manfaatnya bersifat sementara dengan tujuan memenuhi kebutuhan jangka pendek masyarakat Talang Mamak melalui kegiatan berbagi pada program Sekolah Literasi Indonesia. Sementara praktik filantropi modern ditandai dengan upaya pendampingan, pembinaan dan pemberdayaan Komunitas Talang Mamak di 
Desa Rantau Langsat khususnya dalam memenuhi kebutuhan akan pendidikan secara berkelanjutan dan bersifat jangka panjang (Dede, Wawancara, Kamis, 31 Januari 2019).

Praktik filantropi tradisional pada program Sekolah Literasi Indonesia ini lebih mengarah kepada personal masyarakat Talang Mamak, namun manfaatnya dapat dirasakan oleh masyarakat Talang Mamak khususnya Dusun Nunusan, dalam rangka memenuhi kebutuhan mereka akan adanya layanan dan fasilitas pendidikan secara langsung. Salah satu praktik filantropi tradisional dari program Sekolah Literasi Indonesia yang membawa kesan penting bagi masyarakat Talang Mamak adalah adanya bantuan parsel pendidikan berupa pemenuhan kebutuhan akan perlengkapan sekolah lengkap, seperti pakaian seragam, sepatu, buku dan sebagainya. Hal ini bertujuan untuk memenuhi kebutuhan langsung yang bersifat jangka pendek yang sebelumnya belum terpenuhi. Sebagaimana dikatakan oleh Iman, seorang siswa sekolah jarak jauh di Dusun Nunusan, yang mengutarakan:

"Kami belajar disini, awalnya pakai baju ala kadarnya, tidak seragam, tidak pakai sepatu, dan belajar ditempat sederhana, buku panduan belajar tidak mencukupi, ya.. pokoknya hanya memanfaatkan fasilitas yang ada. Kami pun sering libur. Terkadang kami sering menanyakan ke guru, kapan lagi sekolah, kapan kami punya baju seragam dengan perasaan sedih. Tapi, ya belum juga terpenuhi. Akhirnya, ada guru yang di datangkan untuk mengajar di sini, ada bantuan baju seragam, sepatu, buku tulis, buku panduan dan bacaan untuk anak-anak, ya kami merasa senang dan bangga, kami semua dapat bantuan tanpa terkecuali” (Iman, Wawancara, Selasa 29 Januari 2019).

\section{Gambar 1. Pemberian Parsel Pendidikan Lengkap untuk Anak-anak Talang Mamak}

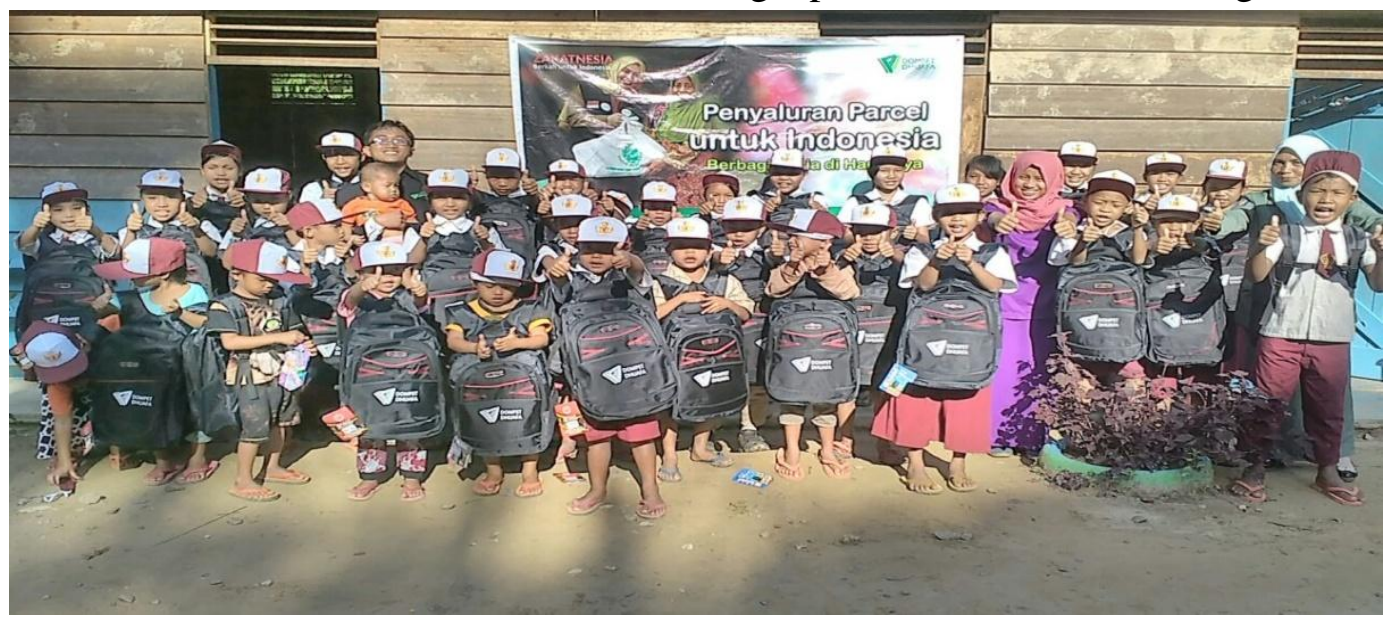

Sumber: http://www.makmalpendidikan.net/berbagi-parsel-pendidikan-di-pedalaman/, diakses pada hari Kamis, 01 Oktober 2020

Dede Agus Salim Rahman mengatakan bahwa kegiatan berbagi bantuan berupa parsel pendidikan tersebut merupakan bagian dari program Sekolah Literasi Indonesia yang awal dilakukan ketika program ini mulai dilaksanakan di Dusun Nunusan dengan tujuan dapat memotivasi mereka untuk semangat belajar meskipun dalam keterbatasan dan keterbelakangan, dan sebagai bentuk aktivitas filantropi yang direalisasikan dalam bentuk kepedulian dan tanggung jawab sosial melalui kegiatan memberi bantuan langsung kepada masing-masing siswa (Dede, Wawancara, Kamis, 29 Januari 2019). 
Selain pemberian parsel pendidikan, praktik filantropi tradisional yang mengarah pada bentuk karitas atau pelayanan langsung lainnya adalah memberikan bantuan beasiswa pada guru lokal yang mengajar di Sekolah Jarak Jauh dengan memberikan kesempatan untuk melanjutkan perkuliahan secara gratis dengan beasiswa dari Dompet Dhuafa Riau melalui program Sekolah Literasi Indonesia untuk Komunitas Talang Mamak khsusunya di Dusun Nunusan. Ali Bastoni mengatakan bahwa pemberian beasiswa untuk mengikuti perkuliahan bagi tenaga pengajar lokal di sekolah jarak jauh di Dusun Nunusan bertujuan untuk mengangkat harkat guru pedalaman yang jarang bahkan belum sama sekali mendapatkan kesempatan untuk mengikuti perkuliahan (Ali Bastoni, Wawancara, Rabu, 05 Februari 2019).

Ali Bastoni menambahkan bahwa dengan adanya pemberian beasiswa tersebut, memberikan kesempatan kepada guru yang merupakan satu-satunya tenaga pengajar lokal di Dusun Nunusan untuk beradaptasi dengan dunia luar, mendapatkan ilmu yang lebih luas, dan pengalaman yang lebih dari sebelumnya. Sehingga pengalaman dan ilmu yang dia dapatkan di bangku perkuliahan, dapat diterapkannya untuk mutu dan kualitas pendidikan anak-anak serta masyarakat Talang Mamak di Dusun Nunusan secara berkelanjutan nantinya, meskipun program pemberdayaan untuk mereka telah selesai dilaksanakan sesuai dengan waktu yang ditentukanperkuliahan (Ali Bastoni, Wawancara, Rabu, 05 Februari 2019).

Peneliti melihat bahwa kegiatan karitas atau pemberian langsung yang dilaksanakan tersebut adalah sebagai bentuk upaya penyaluran hak-hak kaum yang membutuhkan dari sebagian harta para aghniya' (orang-orang kaya) yang dilakukan oleh Dompet Dhuafa Riau sebagai lembaga penghimpun dana-dana filantropi seperti zakat, infaq, sedekah dan wakaf. Hal ini tentu sejalan dengan pernyataan al-Qur'an yang mengatakan bahwa di dalam harta orang-orang kaya terdapat hak-hak orang lain yang membutuhkan (QS. Adz-Dariyat: 19). Dengan demikian, apa yang dilakukan oleh Dompet Dhuafa tersebut, adalah sebagai bentuk pemenuhan hak-hak Komunitas Talang Mamak sebagai kaum yang membutuhkan dari dana filantropi yang dihimpun melalui sebagian harta masyarakat atau para donatur yang tergolong orang-orang mampu.

Selanjutnya, praktik filantropi yang mengarah pada tujuan jangka panjang atau praktik filantropi modern pada pelaksanaan program Sekolah Literasi Indonesia ditandai dengan program pendampingan, pembinaan dan pemberdayaan. Program pendampingan direalisasikan dalam bentuk kegiatan belajar dan mengajar.

Gambar 2. Kegiatan Belajar Mengajar pada Program SLI di Sekolah Jarak Jauh Dusun Nunusan, Talang Mamak

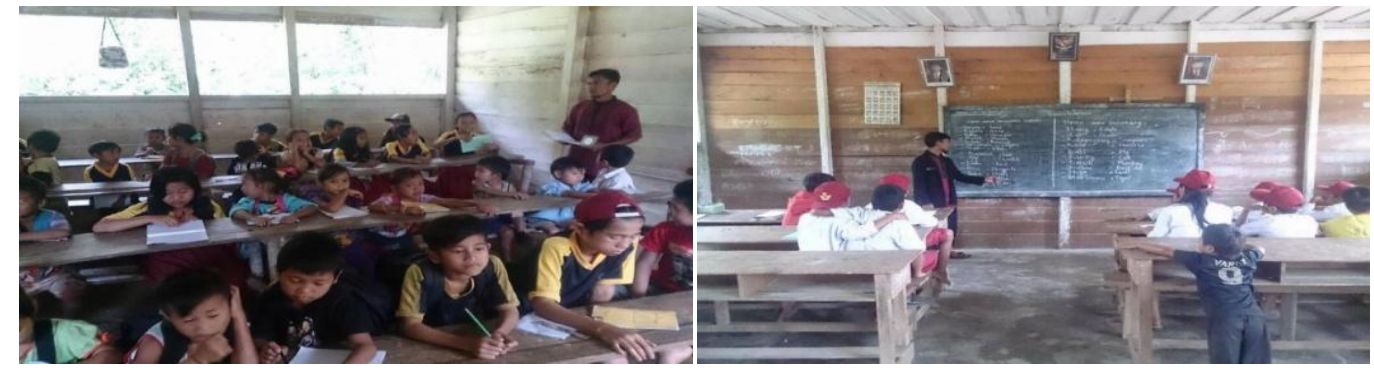

Sumber: Laporan Tahunan Dompet Dhuafa Riau, Annual Report 2018,(DD Riau, 2019:9) 
Kegiatan belajar mengajar dilaksanakan dan digerakkan oleh guru sebagai konsultan relawan yang dikirimkan oleh Dompet Dhuafa Riau melalui kerjasama Dompet Dhuafa Pusat dalam rangka mendamping dan menjalankan aktivitas pendidikan di Dusun Nunusan. Kegiatan ini dilakukan di Sekolah Jarak Jauh Dusun Nunusan setiap harinya kecuali minggu sebagaimana aktivitas belajar di sekolah-sekolah pada umumnya. Kegiatan belajar dan mengajar dimulai setiap pukul 07.30 WIB pagi sampai jam 12.00 WIB siang. Sebagaimana Oky, sebagai konsultan Relawan dari Program SLI yang dikirimkan oleh Dompet Dhuafa Pusat untuk menjalankan program ini di Dusun Nunusan, mengatakan:

"Kegiatan belajar pada program Sekolah Literasi ini dilaksanakan setiap hari senin sampai dengan sabtu, dari pagi sampai siang seperti sekolah pada umumnya. Sistemnya, di Sekolah Jarak Jauh di Dusun Nunusan ini hanya terdapat dua ruang kelas saja. Jadi, satu ruang untuk kelas 1 dan 2. Sementara ruang berikutnya kami mengajar kelas 3, 4 dan 5 dan juga kelas 6. Namun untuk tahun ini belum ada kelas 6". Materi utama yang menjadi sasaran pokok yang kami laksanakan berkaitan dengan hal membaca, menulis dan berhitung, dengan harapan anak-anak Talang Mamak di sini tidak lagi buta aksara sebagaimana sebelumnya, mereka mandiri dan mampu dalam tiga hal itu nantinya (Oky, Wawancara, Kamis, 31 Januari 2019).

Pelaksanaan kegiatan belajar dan mengajar di Sekolah jarak Jauh Dusun Nunusan tersebut berdasarkan pada koordinasi guru relawan dengan Kepala Sekolah Dasar Negeri 004 Desa Rantang Langsat terkait materi dan teknis dalam pelaksnaan dengan memperhatikan kebutuhan anak-anak di Dusun Nunusan.

"Anak-anak di sekolah jarak jauh di Dusun Nunusan, dapat dikatakan banyak bahkan rata-rata masih buta aksara. Jadi, dengan adanya program Sekolah Literasi Indonesia dari Dompet Dhuafa ini, saya berharap banyak kepada mereka melalui guru yang dikirimkan, untuk fokus pada peningkatan kemampuan anak-anak di sana dalam membaca, menulis dan berhitung, karena tujuan utama saya untuk pendidikan anakanak disana adalah kemampuan dalam 3 hal tersebut. Pandai dan mampu anak-anak di sana dalam 3 bidang tersebut, itu sudah luar biasa dan suatu perubahan yang kami dambakan" (Warni Berta, Wawancara, Selasa, 29 Jnauari 2019).

Pelaksanaan praktik filantropi modern pada program Sekolah Literasi Indonesia yang juga tidak kalah pentingnya adalah kegiatan pembinaan. Kegiatan ini direalisasikan dalam bentuk kegiatan pelatihan guna membina guru-guru tempatan yang mampuni agar mereka mandiri, sehingga kedepannya mereka tidak lagi terlalu bergantung pada guru luar atau yang didatangkan. Misalnya gurunya diberi pelatihan bagaimana guru itu mampu mengajar dengan baik dan membuat kegiatan untuk pengembangan potensi siswa, membuat berbagai kegiatan lomba, mampu mengajar dan melaksanakan berbagai kegiatan setelah mereka ditinggalkan untuk melanjutkan perjuangan Dompet Dhuafa Riau untuk pendidikan masyarakat Talang Mamak, bahkan tujuan akhirnya adalah bagaimana guru lokal tersebut mampu mengembangkan potensi dirinya dan diharapkan mampu menjadi peneliti.. Kegiatan ini adalah sebagai upaya mengkader masyarakat tempatan agar mandiri dan mampu menjalankan aktivitas pendidikan nantinya secara berkelanjutan (Oky, Wawancara, Kamis, 31 Januari 2019). 
Kegiatan pembinaan sebagai praktik filantropi modern pada program Sekolah Literasi Indonesia juga direalisasikan dalam bentuk memberikan kesempatan kepada Kepala Sekolah Dasar Negeri 004 Rantau Langsat yang merupakan payung atau sekolah induk bagi sekolah jarak jauh di Dusun Nunusan, untuk mengikuti pelatihan sekolah literasi di Bogor. Sebagaimana Warni Berta mengatakan:

"Baru kali ini, saya sebagai kepala sekolah di daerah pedalaman diperhatikan dan diberdayakan, diberikan kesempatan kepada saya untuk mengikuti pelatihan sekolah literasi bagi kepala sekolah se Indonesia di Bogor. Kesempatan ini belum pernah saya dapatkan. Dengan program Sekolah Literasi Indonesia yang dilaksanakan oleh Dompet Dhuafa Riau di kampung kami, saya mendapatkan kesempatan itu, bahkan sebanyak dua kali saya ikut pelatihan di Bogor, bergabung dengan Kepala Sekolah dari berbagai daerah di Indonesia. Ini adalah sebagai bentuk belas kasih dan pemberdayaan bagi saya khususnya dan masyarakat Talang Mamak pada umumnya, karena ilmu yang saya dapatkan selama pelatihan, dapat saya terapkan di sekolah inti dan sekolah jarak jauh untuk kulaitas pendidikan anak-anak di sini” (Warni Berta, Wawancara, Selasa 29 Januari 2019).

Memberikan kesempatan untuk mengikuti pelatihan bagi Kepala Sekolah SDN 004 Rantau Langsat, adalah sebagai bentuk upaya pembinaan dan pengkaderanyang bertujuan untuk memberikan pemahaman tentang maksud, visi dan misi dari program Sekolah Literasi Indonesia. Sehingga ketika kepala sekolah inti di Desa Rantau Langsat sebagai penggerak Sekolah Jarak Jauh di Dusun Nunusan, mengetahui visi dan misi dari program ini maka akan memudahkan terlaksananya program pemberdayaan masyarakat Talang Mamak di bidang pendidikan melalui pelaksanaan program Sekolah Literasi Indonesia, sebab dia lah yang nantinya akan melanjutkan perjuangan Dompet Dhuafa Riau untuk pendidikan anak-anak Talang Mamak umumnya dan anak-anak di Dusun Nunusan khususnya (Dede, Wawancara, Kamis 31 Januari 2019).

Lebih luas, praktik filantropi modern pada program Sekolah Literasi Indonesia adalah upaya pemberdayaan masyarakat. Kegiatan pemberdayaan direalisasikan dalam bentuk pelatihan pengembangan keluarga (parenting) dan pelatihan pengembangan masyarakat. Pada kegiatan parenting ini, guru sebagai konsultan relawan Dompet Dhufa yang dikirimkan dan menetap di Dusun Nunusan juga mengajar masyarakat dalam membaca, menulis dan berhitung. Kegiatan ini dilatarbelakangi oleh banyaknya masyarakat yang buta aksara. Kegiatan belajar masyarakat ini dilaksanakan di Sekolah Jarak Jauh di Dusun Nunusan tersebut setiap sore Jumat dan Sabtu.Kegiatan ini juga bertujuan untuk memotivasi masyarakat, khsususnya para orang tua untuk lebih memperhatikan pendidikan anakanaknya, yang sebelumnya kurang diperhatikan karena tidak ada dukungan. Dengan kata lain, kegiatan ini sebagai bentuk dukungan terhadap orang tua untuk menyuruh anak-anaknya sekolah serta agar masyarakat juga mendapatkan kesempatan untuk mendapatkan ilmu pengetahuan. Kegiatan tersebut adalah sebuah pergerakan pencerahan dan kebangkitan bagi masyarakat Talang Mamak dari keterpurukan, keterbelakangan dalam upaya terwujudnya perubahan sosial ke arah yang lebih baik dari sebelumnya (Oky, Wawancara, Kamis, 31 Januari 2019). 
Hal tersebut senada dengan ungkapan Zuly Qodir yang mengatakan bahwa proses pemberdayaan berarti proses perubahan. Hal ini akan terwujud melalui suatu pergerakan sosial yang dilakukan oleh para aktor yang berasal dari suatu organisasi maupun lembaga sosial dengan cara melibatkan kelompok-kelompok kecil dalam masyarakat akar rumput, memprakarsai gerakan-gerakan kelompok kecil, membidik isu-isu lokal, melakukan upaya sadar untuk belajar dari pengalaman masa lalu serta memotivasi dan memberikan dukungan untuk bangkit menuju suatu perubahan dari masa lalu (Zuly Qadir, 2009: 246). Di samping itu, hal tersebut juga senada dengan maksud dan tujuan dari adanya aktivitas pemberdayaan. Sebagaimana Sa'adah (2005:2), mengatakanpemberdayaan masyarakat secara sederhana dapat diartikan sebagai upaya untuk memberdayakan mereka yang menjadi sasaran pemberdayaan menjadi masyarakat yang berdaya dan mandiri terhadap bidang pemberdayaan yang dilakukan, baik oleh individu maupun kelompok atau suatu lembaga.

Pelaksanaan program Literasi Indonesia pada Komunitas Talang Mamak dengan pola pendampingan, pembinaan, serta pemberdayaan sebagaiman disebutkan di atas, dilaksanakan selama 3 tahun, dan selanjutnya adalah kegiatan pengawasan secara terus menerus dan berkelanjutan dalam rangka meningkatkan kapasitas dan kualitas pendidikan mereka, meskipun program pendampingan selama tiga tahun telah selesai dilaksanakan. Dengan demikian, Dompet Dhufa Riau melalui program ini adalah sebagai inisiator dalam memberikan pelayanan dan akses serta memberdayakan Komunitas Talang Mamak agar mandiri dan berdaya, sehingga mereka nantinya dapat aktif dalam menjalankan aktivitas pendidikan secara mandiri. Hal ini sejalan dengan tujuan dari program pemberdayaan itu sendiri. Ali Aziz (2005: 136), mengatakan bahwa pemberdayaan masyarakat merupakan suatu proses mendorong masyarakat khususnya mereka yang kurang memiliki akses ke sumber daya pembangunan misalnya kaum marginal dan pedalaman untuk meningkatkan kemandirian dalam mengembangkan perikehidupan mereka. Disamping itu, pemberdayaan masyarakat merupakan proses siklus terus-menerus dengan melibatkan partisipasi masyarakat sebagai anggota pemberdayaan.

Penulis mengamati bahwa pelaksanaan program Sekolah Literasi Indoenesia sebagaimana dijabarkan di atas, adalah suatu bentuk pendistribusian dana filantropi berupa zakat, infaq, sedekah dan wakaf untuk program-program kreatif yang bersifat jangka panjang melalui program pemberdayaan masyarakat, sehingga cakupan penerima manfaat dari dana filantropi tersebut lebih luas termasuk masyarakat di daerah pedalaman. Ini adalah sebagai upaya peralihan fungsi dana filantropi terutama zakat dari manfaat jangka pendek kepada manfaat jangka panjang dan menyeluruh. Hal ini sejalan dengan ungkapan Retsikas dalam artikelnya yang mengatakan bahwa zakat memiliki fungsi dimensi sosial dan memiliki hubungan dengan keadilan sosial. Keadilan sosial akan terwujud jika adanya perubahan pada pendayagunaan dana zakat dari bentuk karitas yang berorientasi pada bantuan jangka pendek kepada bentuk pemberdayaan jangka panjang untuk kesejahteraan masyarakat secara menyeluruh, sehingga zakat mampu menjadi pranata sosial masyarakat (Retsikas, 2014: 337357)

Firman Nuryanto juga mengatakan bahwa hadirnya Dompet Dhuafa Riau bertujuan untuk bisa berbuat banyak terhadap masyarakat di Provinsi Riau pada umumnya. Berupaya 
agar zakat tidak hanya tersalurkan pada individu yang manfaatnya bersifat sementara, namun mendorong masyarakat untuk berzakat, berinfaq, bersedekah dan berwakaf melalui lembaga ini, sehingga manfaat dana filantropi dapat dirasakan oleh masyarakat banyak, termasuk di daerah pedalaman melalui pelaksanaan program-program pemberdayaan jangka panjang sesuai kebutuhan dari masyarakat yang menjadi sasaran pelaksanaan program (Firman, Wawancara, Selasa, 22 Januari 2019).

Berdasarkan uraian di atas, penulis melihat bahwa Dompet Dhuafa Riau sebagai lembaga filantropi Islam telah menunjukkan perannya dalam merubah fungsi dana zakat, infaq, sedekah dan wakaf untuk program jangka panjang melalui program pemberdayaan berkelanjutan dengan melaksanakan program Sekolah Literasi Indonesia untuk pemberdayaan masyarakat Talang Mamak di Desa Rantau Langsat di bidang dakwah dan pendidikan dengan tujuan terwujudnya masyarakat yang mandiri dan berdaya dalam kedua bidang tersebut yang menjadi kebutuhan penting bagi Komunitas Talang Mamak.

Lebih dari itu, pelaksanaan program Sekolah Literasi Idonesia dapat dibaca sebagai adanya keterlibatan Lembaga Amil Zakat sebagai aktor non negara dalam upaya penyelesaian isu sosial pada masyarakat akar rumput terutama masyarakat yang kurang beruntung. Keterlibatan tersebut direalisasikan dalam upaya pendistribusian kesejahteraan dan kesetaraan sosial melalui pelaksanaan program berdasarkan pada kebutuhan masyarakat dengan memanfaatkan dana filantropi yang berhasil dihimpun. Sebagaimana Minako Sakai menegaskan bahwa hadirnya organisasi atau lembaga sosial berbasis agama seperti halnya lembaga filantropi adalah berupaya memberikan pelayanan dan kesempatan kepada orangorang di level akar-rumput untuk ikut terlibat secara aktif dan efektif melalui program atau kegiatan-kegiatan yang berkelanjutan. Lembaga filantropi tersebut adalah sebagai aktor non negara dalam membantu negara guna mendistribusikan kejahteraan bagi masyarakat yang tidak terjangkau oleh perhatian negara secara penuh (Sakai, 2018: 49-50). Peneliti melihat bahwa hal tersebutlah yang dirasakan oleh Komunitas Talang Mamak. Masyarakat yang tinggal di pedalaman yang kurang beruntung, kurang dukungan serta kurang diperhatikan, dapat merasakan secara langsung manfaat dari dana filantropi yang diinisiasi oleh Lembaga Amil Zakat Dompet Dhuafa Riau. Dengan adanya program Sekolah Literasi Indonesia untuk pembinaan dan pemberdayaan Komunitas Talang Mamak adalah sebuah langkah baru yang membawa perubahan besar bagi kehidupan mereka, yang dapat membawa mereka keluar dari kondisi primitif atau keterbelakangan yang selama ini terabaikan. Hal ini diutarakan oleh Safarudin, yang mengatakan:

"Kami menilai ini adalah sebuah pencerahan dari kegelapan dalam kehidupan kami di sini. Saya salut dengan tekad mereka, mereka mau berjuang, mau menetap didaerah kami yang pelosok dan pedalaman ini, mau membina kami, semua itu mereka lakukan dengan percuma atau tidak mengharapkan apa-apa. Tidak ada layanan pendidikan dan fasilitas memadaidi tempat kami, mereka adakan dan fasilitasi kebutuhan kami. Yang biasanya kegiatan pendidikan di Dusun Nunusa terhambat, bahkan tak jalan, sekarang sudah mulai berjalan kembali. Anak-anak di sana sudah mulai pandai membaca dan berhitung.Yang dulu aktivitas pendidikan sangat sulit dan tidak berjalan di sana, sekarang menjadi aktif. Dengan program SLI ini, dengan masukknya para guru relawan di kampung kami ini, membawa pencerahan dam perubahan besar bagi kami. Ini adalah 
bukti kepedulian mereka kepada saudara-saudaranya yang tinggal di hutan daerah pelosok dan pedalaman ini” (Safarudin, Wawancara, Rabu, 30 Januari 2029).

Dari uraian di atas, pelaksanaan program Sekolah Literasi Indonesia yang diinisiasi oleh Dompet Dhuafa Riau pada Komunitas Talang Mamak tersebut, dapat dibaca sebagai sebuah pergerakan Lembaga Amil Zakat sebagai aktor non negara dalam mendistribusikan kesetaraan dan mewujudkan kesejahteraan masyarakat. Program tersebut merupakan program kreatif dengan skema filantropi Islam yang mengarah pada upaya pemberdayaan melalui pemenuhan kebutuhan masyarakat baik jangka pendek maupun jangka panjang yang dapat mengisi kekosongan negara dalam mensejahterakan masyarakat terutama bagi masyarakat pedalaman yang kurang diperhatikan.

\section{Simpulan}

Program Sekolah Literasi Indonesia yang diinisiasi oleh Dompet Dhuafa Riau pada Komunitas Talang Mamak dilatarbelakangi oleh keadaan komunitas tersebut yang tinggal di daerah pedalaman dan berada dalam kondisi keterbelakangan, ketertinggalan terutama dalam bidang pendidikan, sehingga perlu diberdayakan. Program ini bertujuan untuk mewujudkan keberdayaan dan kemandirian serta memenuhi kebutuhan masyarakat Talang Mamak baik jangka pendek maupun jangka panjang dengan pola pendampingan, pembinaan dan pemberdayaan.

Program Sekolah Literasi Indonesia yang bergerak dalam bidang pendidikan ini dilaksanakan dengan merevitalisasi skema filantropi Islam terutama mendayagunakan dana zakat, infaq, sedekah dan wakaf serta sumbangan dari para donatur yang berhasil dihimpun. Artikel ini menunjukkan bahwa praktik filantropi Islam yang dilakukan pada program ini, tidak hanya bersifat konsumtif dan jangka pendek, tetapi juga mengarah pada aktivitas pemberdayaan dalam rangka mewujudkan keberdayaan dan kemandirian Komunitas Talang Mamak sebagai masyarakat yang perlu diberdayakan terutama bidang pendidikan. Di samping itu, pelaksanaan program Sekolah Literasi ini menunjukkan bahwa Dompet Dhuafa Riau telah melaksanakan perannya sebagai aktor non negara dalam mendistribusikan kesejahteraan sosial yang diarahkan pada masyarakat kurang beruntung dan belum tersentuh oleh perhatian negara.

\section{Referensi}

Ali, Mohammad. (2011). Memahami Riset Prilaku dan Sosial. Bandung: Pustaka Cendekia Utama.

Aziz, A.M. (2005). Dakwah Pemberdayaan Masyarakat: Paradigma Aksi Metodologi. Yogyakarta: Pusataka Pesantren.

Dokumen Dompet Dhuafa Riau terkait Program Sekolah Literasi Indonesia 2017.

Fauziah, A. (2016). Filantropi Islam: Sejarah dan Kontestai Masyarakat Sipil dan Negara di Indonesia.terj. Eva Mushoffa. Yogyakarta: Gading Publishing.

Fuadi, A.(2012). Towards the Discourse of Islamic Philanthropy for Social Justice in Indonesia. Jurnal Afkaruna, 8 (2), 92-102.

Latief, H. (2017). Melayani Umat: Filantropi Islam dan Ideologi Kesejahteraan Kaum Modernis.Yogyakarta: Suara Muhammadiyah. 
Latief, H. (2013).Politik Filantropi Islam di Indonesia: Negara, Pasar dan Masyarakat.Yogyakarta: Penerbit Ombak.

Latief, H. \&Zaenal M. (2015). Islam dan Urusan Kemanusiaan. Jakarta: PT Serambi Ilmu Semesta.

Latief, H. (2010). Health Provision for the Poor: Islamic Aid and the Rise of Charitable Clinics in Indonesia.South East Asia Research, 18(3), 503-553.

Martin, W.M. (1994).Virtous Giving: Philanthropy, Voluntary Service and Caring. Bloomington: Indiana University Press.

Qadir, Z.(2009) Gerakan Sosial Islam: Manifesto Kaum Beriman. Yogyakarta: Pustaka Pelajar.

Retsikas, K. (2014). Reconseptualising Zakat in Indonesia: Worship, Philanthropy and Right. Indonesia and the Malay World, 42 (124), 337-357.

Sa'adah, N. (2015).Pemberdayaan Masyarakat Marginal. Yogyakarta: Pustaka Pelajar.

Sakai, M. (2018). Penggiat Bisnis Syariah: Muslimah, Kewirausahaan dan Pemberdayaan Masyarakat, terj. M Falikul Isbah dan Najib Kailani. Jakarta: Dompet Dhuafa.

Sakai, M. (2014). Establishing Social Justice Trough Financial Inclusivity: Islamic Propagation by Islamic Savings and Credit Cooperatives in Indonesia. TraNS: TransRegional andNational Studies of Southeast Asia, 2 (2), 201-222.

Soetarso.(1994). Praktek Pekerjaan Sosial dalam Pembangunan Masyarakat. Bandung: Koperasi Mahasiswa Sekolah Tinggi Kesejahteraan Sosial.

Tim Penyusun. (2019). Laporan Tahunan Dompet Dhuafa Riau, Annual Report 2018. Pekanbaru: Dompet Dhuafa Riau.

Yefni, dkk. (2014). Pengembangan Masyarakat Islam. Yogyakarta: Pandiva Buku.

\section{Daftar Wawancara}

Wawancara dengan Ali Bastoni, Pimpinan Cabang Dompet Dhuafa Riau, Rabu, 05 Februari 2019.

Wawancara dengan Firman Nuryanto, Manajer Program Pemberdayaan dan Jejaring Dompet Dhuafa Riau, Selasa, 22 Januari 2019

Wawancara dengan Dede Agussalim Rahman, Kepala Perwakilan Dompet Dhuafa Riau untuk wilayah Kabupaten Indragiri Hulu dan Koordinator Program Pemberdayaan Komunitas Talang Mamak, Kamis, 31 Januari 2019.

Wawancara dengan Oky Dwi Ramadiansyah, Tenaga Pengajar/Konsultan Relawan SLI, Kamis, 31 Januari 2019

Wawancara dengan Safarudin (Pak Taktung), Tokoh Adat dan Pendidikan Komunitas Talang Mamak, Rabu, 30 Januari 2019.

Wawancara dengan Warni Berta, Kepala Sekolah Dasar Negeri 004 Rantau Langsat, Selasa, 29 Januari 2019

Wawancara dengan Iman, Siswa Sekolah Jarak Jauh Dusun Nunusan, Selasa, 29 Januari 2019

\section{Daftar Web}

Berbagi Parsel Pendidikan untuk Anak-anak Talang Mamak dalam http://www.makmalpendidikan.net/berbagi-parsel-pendidikan-di-pedalaman/, diakses pada hari Kamis, 01 Oktober 2020 